
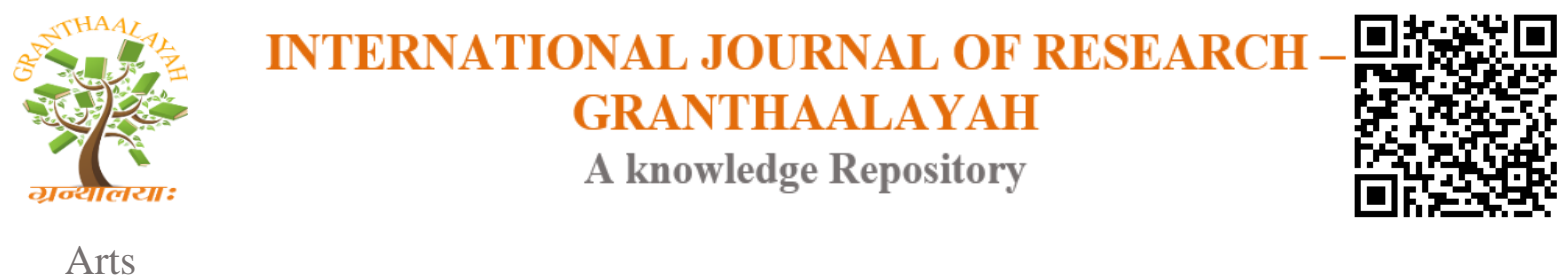

Arts

\title{
ONLINE ART GALLERY
}

\author{
Abhilasha Jaiswal ${ }^{* 1}$ \\ ${ }^{* 1}$ DAVV University, Indore, MP, India
}

\begin{abstract}
An online art gallery is new concept of selling and purchasing art works, both digital prints and traditional paintings are available on online sites. Basically, it is a user interface kind of web page on which buyer and seller both gets a platform for their jobs. Online art gallery is a time, energy and money saving web site concept. By this artist also can host their works and art curator can arrange auctions for art works.
\end{abstract}

Keywords: Art Gallery.

Cite This Article: Abhilasha Jaiswal. (2018). “ONLINE ART GALLERY.” International Journal of Research - Granthaalayah, 6(6), 403-406. 10.29121/granthaalayah.v6.i6.2018.1386.

\section{Introduction}

Online art gallery is kind of web page or website that you can put your art work images for viewing. Usually, nowadays everything is available on online shopping market so why not art works. Every kind of painting either they are traditional medium based or digital art based you can get it online. On some online art gallery website the galleries also conduct art auctions.

On that buyer come to invite place, and they start biding on particular art work, who bid the highest price they will be owned that art work. The purpose of online art gallery is to reach art works every corner of world by using technology. When everywhere things are available on online then why art works leave behind. So online art gallery is a system or a program where the art collector can view, select and purchase art work within their comfort zone.

Online art gallery is a user based website in which artist can upload their art images and buyer can view these images, choose and purchase. This concept helps people who are not available to visit the place on particular time due to some constraints. They open the site, go through it and choose what they like.

Through this digitalization we can stay connected to every corner of the world. And this connectivity of art exhibitions also become online in that the viewership increased and selling of art works also increased. These art galleries had started these virtual art galleries concepts. Art works is communicated by the combinational form of the display/exhibition; it is not just an 
architectural space. Now days, the internet has became a global language of communication this medium offers new and very unique opportunity for artist to grow themselves by selling their art works online.

The old classical concept of galleries has twisted into this virtual art gallery concept. In these art curator has no infrastructure or architectural spaces to display their art works, they only need space on cyber to upload images of artist creation and some text explaining the art works. By going through these details buyer/art collector gets a chance to understand that what the art work had. Then according to their requirement they contact to art curator by mail and gets replay to fulfill their query, then further formalities goes. Buyer get their selected art works delivered by through the courier services.

From virtual art galleries artist can reach to a larger population. This kind of galleries also beneficial for artist, also a seller can approach different artist of different places to give their art works and where they don't need to present physically. Abuyer can view and buy any kind of work comfortably at their places.

In last 10 years broadband users increased so improvement of web programming field also get more and more improved the display of online art images. You can zoom on picture to experience the more close view. $3 \mathrm{~d}$ photography and 360 degree view filters has make this thing richer.

By the option of zooming viewer get through the pigmentation or texture of the particular art work. And rest of the details like material, colour, surface, size, and subject is mentioned in text below the image.

Another advantage of online galleries is that the area of people and choice had increased by the internet. Those who don't has the knowledge of art is also trying to understand the art works and get the wide range of art works that they view in the comfort at home.

Online art galleries also have a wider online operations, following are the some popular facilities they provide-

- Latest art news

- Blogs

- Critic reviews

- Event listing

- Gallery listing

- Reviews

- Pricing information

- Art forum

- Desired framing

- Collaboration

- Remote accessibility

- Great master's art work's digital prints 


\section{Advantages of online art gallery-}

Online art gallery is a new concept of trending for modern art lovers who want to purchase art works but unable to come to gallery or being in their comfort zone. Following are some pointers that should be the advantages of online art gallery-

- Art buyers can explore all kind of art works along with digital prints of famous art works of great masters without going anywhere.

- Art viewers can see art works according to their availability of time \& within their comfort.

- On traditional art exhibitions art enthusiasts has to go through all the art galleries to find their desired art medium or artist but on online art gallery, they can search for the same.

- Online art gallery they also guide the buyer about the art works.

- Through online art galleries you can receive purchased art works directly from artist.

- A complete record of art works as well as artist is also available on site.

- They also provide authenticity of work and you can also cross check it through online.

- These sites are also very helpful for young artist so they get exposure by uploading their work on it.

- Buyer can share and suggest their friends, their selected images without wasting time and money.

- Fewer infrastructure is required for virtual art galleries so it is very economic.

\section{Conclusion}

In a nutshell, online art galleries are the future scope of selling, exhibiting the art works market. Gradually it will be more and more improved and grow throughout the world.

Now they had also started using the 360 degree view and panoramic image for better feel of the virtual art gallery experience. Only one possible restriction is faced by that when the reduced the size of image of particular art works they should be sure for the quality and clarity should not be compromised.

At the last I should say that technology is the future of everything so as soon the artists adapt it will be beneficial for art world. The Information era also gives opportunity to virtual art gallery to flourish.

\section{References}

[1] http://history-computer.com/index.html

[2] http://history-computer.com/Internet/Internet.html

[3] https://en.wikipedia.org/wiki/Online_art_gallery

[4] https://www.linkedin.com/pulse/online-art-gallery-revealing-features-advantages-faim-uddin-

[5] http://www.huffingtonpost.com/jason-landry/why-galleries-are-importa_b_4074202.html

[6] http://www.iamwire.com/2015/06/scope-online-art-marketplace-india/118178

[7] https://theabundantartist.com/online-art-galleries/

[8] https://www.widewalls.ch/the-rise-of-online-art-market/

[9] Read, R., 2017, Hiscox Online Art Trade Report 2017, Hiscox [Sep 12, 2017] 
[10] Reyburn, S., 2015, When the Fine Art Market Goes Online, The New York Times [Sep 12, 2017]

[11] Jamieson, A., 2017, Taking the plunge into the online art market, Affordable Art Fair [Sep 12, 2017]

[12] Anonymous, 2017, How to Research Your Online Art Market, The Abundant Artist [Sep 12, 2017]

*Corresponding author.

E-mail address: artist.abhi@gmail.com 